\title{
INVESTIGATION OF WATER LOSS FROM PIPES LOCATED IN VARIOUS RELIEF FEATURES OF IAŞI COUNTY
}

\author{
Ștefania Chirica ${ }^{1}$, Mihail Luca ${ }^{2}$, Iustina Lateș ${ }^{3}$
}

Keywords: detection, equipment, landforms, water supply pipe

\begin{abstract}
Water losses are present in all water supply system pipes. Their parameters and value vary depending on the constructional and functional features of the pipes (diameter, material, pressure, embedding environment, location, position etc.). The phenomenon is present in all water supply systems networks in Romania as well as globally. The water supply pipes within the regional water supply system are located in areas with diversified relief, from plateaus and hills to plains. The studies and researches were carried out in the geographical placement area of the Timişeşti-Iaşi pipeline. The geographic area studied is enclosed in Siret and Prut hydrographic basins. The paper aims to establish a correlation between the detection methods of water leaks from pipes and the areal relief features in Iaşi County. At the same time, it is highlighted the impact of the variation of the geographical relief characteristics on the water loss management on different type of pipes.
\end{abstract}

\section{Introduction}

Water losses in pipes are a phenomenon that has become increasingly larger in recent years. The phenomenon is acutely felt worldwide and nationally. The most technologically advanced countries, such as U.S.A., reach loss values of about 0.67 $\mathrm{m}^{3} /$ year, $\mathrm{m}$ (linear pipe meter) (Sturm et al., 2015). In Romania, the average value of water losses reaches $11.65 \mathrm{~m}^{3} /$ year,m (Racoviţeanu et al., 2015).

According to the methodology established by IWA (International Water Association), physical water losses occur on supply pipes, distribution and valve homes, overflow installations of storage tanks and on connection pipes up to the metering point (Lambert and Hirner, 2000). Water losses on the supply pipes have one of the highest values of the water supply systems (Luca et al., 2015). Main

\footnotetext{
${ }^{1} \mathrm{PhD}$ stud. "Gheorghe Asachi”" Technical University of Iasi, Romania, stefania.chirica@gmail.com

${ }^{2}$ PhD Eng Prof. “Gheorghe Asachi” Technical University of Iasi, Romania, mluca2015@yahoo.com

${ }^{3} \mathrm{PhD}$ stud. "Gheorghe Asachi” Technical University of Iasi, Romania, lates.iustina90@gmail.com
} 
supply pipes are defined by very large diameters and lengths, various building materials, sections with different physical characteristics and locations with various peculiarities. The water loss control is difficult to achieve and emission values increase with the lack of adequate intervention measures. Existing equipment worldwide is diversified and adapted to all situations encountered on the ground. Detection methods range from acoustic instruments, video cameras and robot inspections, drones and ground penetrating radars, to GIS and SCADA systems, hydraulic modelling, or satellite investigations. The latest studies and research highlight the importance of smart water networks and state of the art technical assessment for water distribution systems (Kilinç et al.,2018; Bragalli et al., 2019).

\section{Geographical features in the regional water supply system coverage} area

Regional water supply systems are defined by a large number of interconnected functional components serving a pressurised pipe network (Alexandrescu, 2013). The regional system covers a large land area, comprised of a single county, but also several counties. The system operated by S.C. APAVITAL S.A. serves the localities of Iaşi County, but also a number of localities in Neamt County (Doljeşti, Gherăeşti). In this case, the control and management of water losses is put in difficulty by various pipe types, namely supply, distribution and connection pipes. Iaşi County regional water supply system consists of $922 \mathrm{~km}$ water supply pipes and $2.507 \mathrm{~km}$ distribution pipes. Of these, about $1.099 \mathrm{~km}$ serve the surface of Iaşi metropolitan area and the other $1408 \mathrm{~km}$ cover the county area.

The great variety of land forms crossed by the water supply pipes is highlighted through the Timişeşti - Iaşi main pipes route. The pipes depart from the Timişeşti area at $266 \mathrm{~m}$ elevation and descend towards the storage tanks in Iaşi County, where they reach $47 \mathrm{~m}$ elevation (Fig. 1). The pipes encounter various relief forms, which they can bypass, undercross or overpass. For example, Moldova River is undercrossed by Timişeşti - Iaşi water supply pipes. The same water supply pipes ( 3 in number) overpass Siret River (pipeline I in Rotunda area and pipelines IIa and IIb in Sccheia). Two of them also undercross Strunga Hill. On their route location, these pipes undercross roads and railways.

The supply pipes I and II (made of IIa and IIb pipes) draw off the water volumes extracted from Timişeşti catchment located at a height of $266 \mathrm{~m}$. The three pipelines undercross Moldova River in Soci locality and then continue up to Săbăoani locality at $229 \mathrm{~m}$ elevation. On their route, the three pipelines are joined by pipeline III, which transports water from Mirosloveşti catchment. From Săbăoani, the three pipes follow different routes. Pipeline I descends to Rotunda area, where it reaches the Siret River, which it overpasses using a special structure. The route continues along Oţeleni - Brăeşti - Lungani route and reaches an 
elevation of $82 \mathrm{~m}$ in Sârca village. On this sector, pipe I crosses the hills of Brăeşti, the Oţeleni - Buda and Lungani forests, as well as numerous arable lands and private properties, where access of the water - sewer operator is restricted.

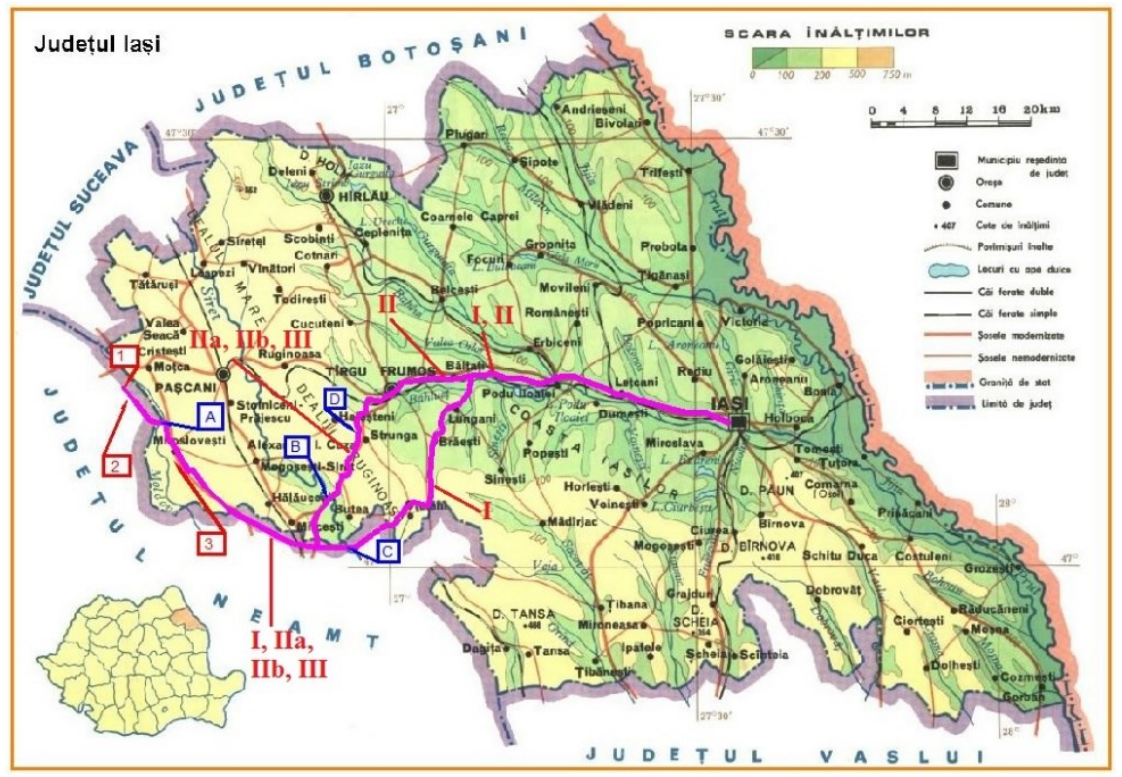

Fig. 1. Timişeşti - Iaşi main supply pipes route; 1 - Timişeşti source,

2 -Zvorăneşti source, 3 - Mirosloveşti source; A - Moldova River undercrossing in Soci; B - Siret River overpassing in Şcheia; C - Siret River overpassing in Rotunda; D - Strunga hydro technical gallery

Pipes II (IIa and IIb) and III go from Săbăoani in the direction of Şcheia Bridge - Trei Iazuri - Strunga along the European road E583. In Şcheia locality the pipes overpass Siret River through a special structure. On the way to Strunga, the pipes cross Ruginoasa Hill. To cross the Strunga Hill, the pipes uses a hydro technical gallery. Pipelines IIa, IIb and III reach the admission chamber located at $250 \mathrm{~m}$. In the exit chamber located at $214 \mathrm{~m}$ the pipes IIa and IIb become a single pipeline II. After undercrossing the Strunga Hill, the supply pipe II descends through Târgu Frumos town to Războieni locality at $83 \mathrm{~m}$. Here the pipeline crosses the Războieni Hill, climbing to the maximum elevation of $112 \mathrm{~m}$, then goes down again until it reaches supply pipe I. The two supply pipes, I and II, join together in Bălţaţi commune, Sârca village, at an elevation of $70 \mathrm{~m}$. The route of the pipes passes through Bahlui Plain and crosses Podu Iloaiei town, the villages of Leţcani and Valea Lupului until it reaches the storage tanks Iaşi city, located at a height of $47 \mathrm{~m}$. 
In the analysis process of the Timişeşti - Iaşi supply pipes, the diversity of geographic conditions is noted. Pipes cross numerous hills and valleys, forests, agricultural land, private property and rivers. Some of the pipes are located under traffic routes (national, county and local roads, railways), but most of them are placed under unenhanced natural lands. In this situation, water loss management must employ techniques, equipment and appliances tailored to the specifics of each situation. Applying a universal methodology for the entire operated surface is difficult to achieve and can introduce significant errors in the quantification of water losses.

\section{Water loss management under the existing relief forms in Iaşi County}

Water supply pipes have the particularity of being located in isolated areas without access roads, which requires a much more difficult and high-cost control. In this situation, water loss detection methods and means have to adapt to landforms, water courses or other obstacles to achieve the most viable results. Among the most versatile network investigation technologies are the ground penetrating radar (G.P.R.), satellite detection and drone equipment (U.A.V.) fitted with sensors adapted to the situation investigated.

One of the most used detection equipment is the ground penetrating radar. The G.P.R. operating mechanism uses an antenna mounted on the mobile device, which transmits an electromagnetic wave into the ground. The response of the underground structures is transmitted in the form of reflected energy. It is received and processed by complex algorithms which describe the embedding environment (Fig. 2.c). The equipment can detect any discontinuity in underground structure (using the dielectric constant and the conductivity of the ground). The impulse wave transmitted by the equipment partially dissipates in contact with rocks with different properties. The wave signal is partially lost, only a portion of it being reflected back to the receiving antenna. Thus, as the dissipated energy increases, there is less available energy to penetrate the ground (Tischler, 2003).

The G.P.R. can be a mobile device, handled by a user (Fig. 2.a) or it can be a device which attaches to a vehicle (Fig. 2.b). In both situations, the G.P.R. provides optimal results only when passing over processed surfaces (paved roads). This condition limits the usefulness and quality of the data obtained. However, the good quality results provided, which make it possible to identify water losses, illegal connections, ground discontinuities (caverns) and underground structures (valve homes, curb boxes), indicate it as the optimal solution for investigating urban networks.

An innovative way to detect water loss is by using a technology created for the discovery of water on other planets, with the help of satellite sensors. In the first stage, the sensors located on satellites acquire images of the study area. Images are 
further transformed by processing and removing vegetation areas, constructions or other obstacles. The final results are the material basis for the process of identifying water losses. The data is then filtered to extrapolate only the elements corresponding to the spectral footprint of the drinking water. The final model is placed over the operator's GIS system and the areas where water losses can be identified are highlighted. From the point of view of efficiency, satellite detection is one of the most useful tools for detecting water losses. The advantages of using the technology come from the large coverage area (thousand $\mathrm{km}^{2}$ ) (Fig. 3.a) and from the confinement of problematic areas to $6 \mathrm{~m}$ diameter surfaces (Fig.3.b). Also, the satellite detection is appreciated by the operators as it can be used in for pipe networks made of any construction materials and diameters, located in all ground types (Schumi, 2017).

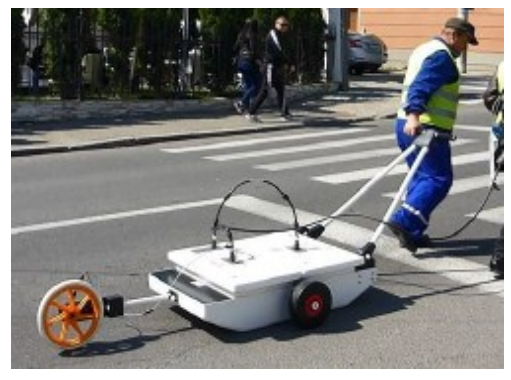

a

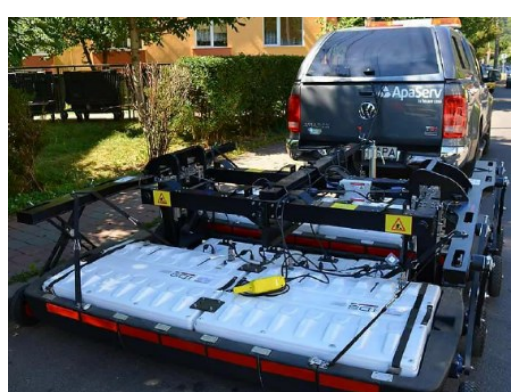

b

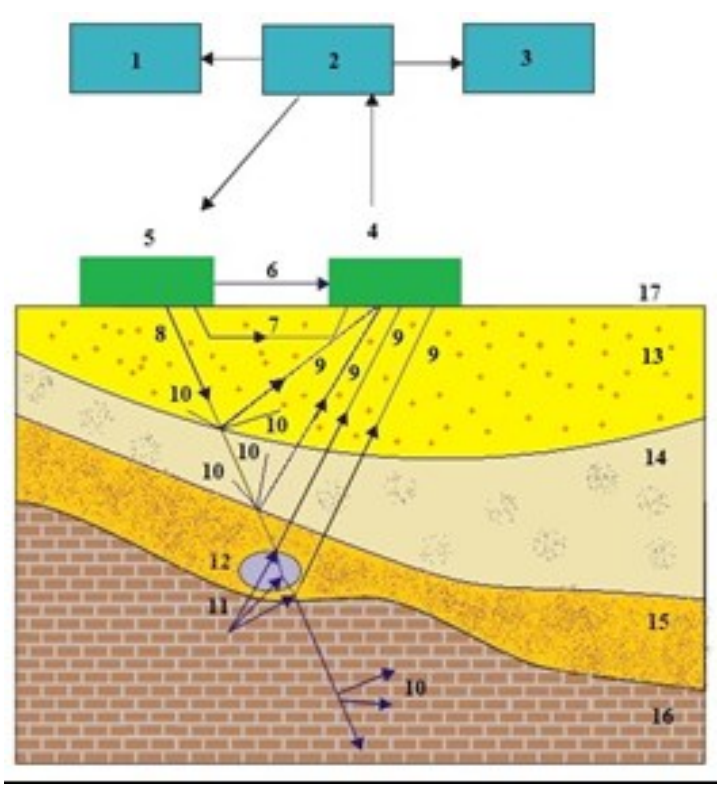

c

Fig. 2. G.P.R.: $a-$ mobile detection equipment (Postăvaru, 2016); b - vehicle attached equipment (Postăvaru, 2016); c - operating principle: 1 - data storage unit, 2 - control unit, 3 display unit, 4 - receiving antenna, 5 - transmission antenna, 6 - direct data transmission, 7 data transfer, 8 - field transmitted impulse, 9 - reflected energy 10 - energy dissipation, 11 refracted energy, 12 - buried object, 13 - 16 - different ground type, 17 - ground surface (Chirica, 2017).

The analysis shows that satellite detection can be used to monitor a wide range 
of locations. It is applicable to all relief forms found on the surface of Iaşi County (hills, valleys, plains). A major advantage is the ability to monitor water losses in hard-to-reach areas, such as private properties or agricultural crops. The Strunga Gallery is one of the most difficult to investigate structures of the water supply system. Being located at depths greater than the rest of the pipe network, the embedding environment is characterised by the presence of groundwater, making it difficult to detect losses using conventional methods. Given that satellite detection is based on the identification of the spectral footprint of drinking water, the detection of water emissions is much easier to achieve. An example of the possible situations can be found in Table 1 .

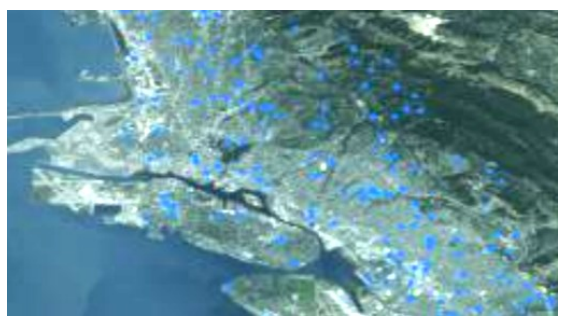

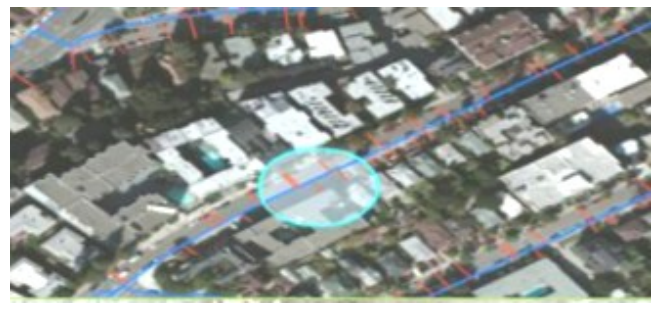

b

Fig. 3. Satellite water loss detection; $\mathrm{a}-$ the area under consideration; $\mathrm{b}$ - water loss location identified (Majetich and Zaibert, 2016)

U.A.V. technology is used to record ground images with the help of cameras placed on flying equipment (drones or small aircrafts). The images recorded correspond to different spectral bands with varying wavelengths. Water emissions

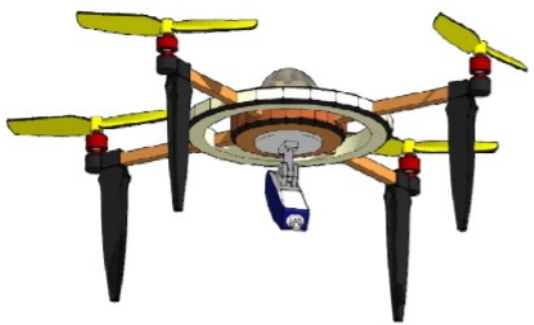

a

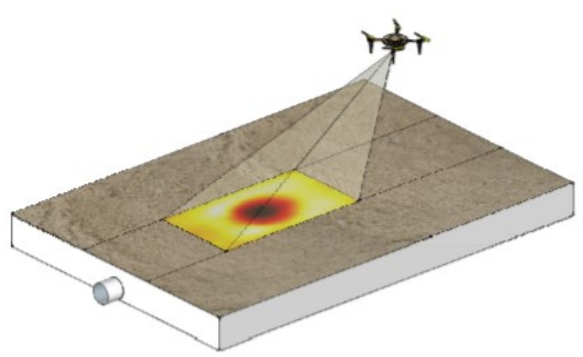

b

Fig. 4. Water loss detection using drones; a - flight equipment, b - working mode (Shakmak and Al-Habaibeh, 2015)

are highlighted by changes in the natural environment in the site area, such as enriching vegetation or changes in soil water content. The cameras used can monitor the thermal radiation emitted by the soil as a result of the increase in 
humidity. They record the cooling of the ground surface after heat exchange with the atmosphere. The thermal radiation registered depends on the nature of the site studied and the density of the vegetation. Depending on the size of the surface investigated, the research may use cameras placed on U.A.V. equipment (Fig. 4), attached to vehicles (Fig. 5) or placed on small airplanes. Drones are used for small surfaces, while planes can cover large land areas. The use of motor vehicles is conditioned by the existence of a roadway on which they can travel.

Thermal imaging cameras record the pipe water discharge area by analysing the temperature difference that occurs between the affected area and the surrounding environment. The technology is very good for the pipes undercrossing Moldova River, considering that the water transported from Timişeşti has a lower temperature than that of the river. The use of thermal imaging cameras is not recommended for wooded areas or areas with abundant vegetation such as agricultural crops.

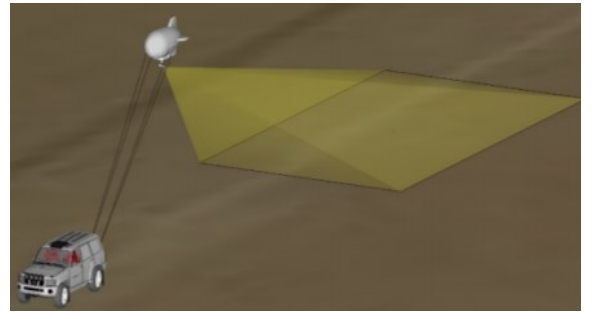

$\mathrm{a}$

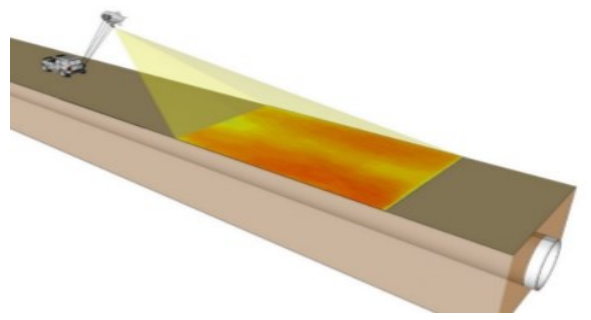

b

Fig. 5. System made of a thermal imaging camera and a GSP system attached to a helium balloon carried by a vehicle; $\mathrm{a}$ - detection equipment; $\mathrm{b}$ - working mode

(Shakmak and Al-Habaibeh, 2015)

The analysis of Table 1 shows that satellite detection may be adopted for the majority of ground characteristics. An exception is the monitoring of the Moldova River undercrossing construction. In this case, the identification of the spectral footprint of the water would be difficult to achieve when the flows and velocities in the riverbed are very high. Research data shows that the use of the ground penetrating radar requires the existence of a runway in order to achieve the best results. For this reason, its applicability is limited to rural networks where most roads are dirt roads or covered with cobblestone. The density of urban underground networks and buildings indicates the G.P.R. as the optimal solution for identifying water losses. 
Tab. 1. Water loss detection technologies adapted to the relief features of Iaşi County

\begin{tabular}{|c|c|c|c|c|}
\hline Location & Exemplification & U.A.V. & Satellite & G.P.R. \\
\hline \multirow{2}{*}{ Rivers } & Moldova River undercrossing & $\mathrm{x}$ & & \\
\hline & Siret River overpassing & $\mathrm{x}$ & $\mathrm{x}$ & \\
\hline \multirow{2}{*}{ Hills } & Strunga hydro technical gallery & & $\mathrm{x}$ & \\
\hline & Brăeşti, Războieni Hills & $\mathrm{x}$ & $\mathrm{x}$ & \\
\hline Plains & Bahlui Plain, Moldova Meadow, Leţcani & $\mathrm{x}$ & $\mathrm{x}$ & \\
\hline Valleys & $\begin{array}{l}\text { Bahlui Depression between Târgu Frumos } \\
\text { and Brăești }\end{array}$ & $\mathrm{x}$ & $\mathrm{x}$ & \\
\hline Forests & Buda - Oţeleni area, Lungani & & $\mathrm{x}$ & \\
\hline $\begin{array}{l}\text { Agricultural } \\
\text { areas }\end{array}$ & $\begin{array}{l}\text { Izvoarele, Soci, Moldova Meadow, } \\
\text { Iugani, Barticeşti, Nisiporeşti, Gherăeşti }\end{array}$ & & $\mathrm{X}$ & \\
\hline Orchards & Sârca & & $\mathrm{x}$ & \\
\hline Private property & Răchiteni, Iugani, Hanul Ancuţei area & $\mathrm{x}$ & $\mathrm{x}$ & \\
\hline \multirow[t]{2}{*}{ Runway } & $\begin{array}{l}\text { Urban networks (Târgu Frumos, Podu } \\
\text { Iloaiei) }\end{array}$ & $\mathrm{X}$ & $\mathrm{X}$ & $\mathrm{X}$ \\
\hline & Rural networks (Brăeşti, Albeşti, Lungani) & $\mathrm{x}$ & $\mathrm{x}$ & \\
\hline
\end{tabular}

\section{Conclusions}

1. The complexity of supply pipes, characterised by wide territorial expansion, is a major problem in the management of water supply systems.

2. Non-invasive pipe investigation methods are among the most sought-after water supply monitoring solutions, due to their low impact on consumers (the interruption of drinking water supply is not required).

3. Fast results obtained using modern detection equipment limit the value of water losses, with favourable implications for economic and environmental factors.

4. The wide variety of water loss detection solutions covers all the geographical features of the area operated.

\section{References}

Alexandrescu, Simona Adina, 2013, Contribuții la optimizarea hidraulică și funcţională a sistemelor regionale de alimentare cu apă. Teză de doctorat. Universitatea Tehnică „Gheorghe Asachi” din Iaşi.pp. 10 - 29.

Bragalli, Cristiana, Neri, M., Toth, Elena, 2019, Effectiveness of smart meter-based urban water loss assessment in a real network with synchronous and incomplete readings. Environmental Modelling and Software 112 (2019), pp. 128-142.

Chirica, Ştefania, 2017, Raport de cercetare ştiinţifică nr. 1. Studiu documentar privind influenţa pierderilor de apă asupra managementului sistemelor de alimentare cu apă a localităţilor. Universitatea Tehnică „Gheorghe Asachi” din Iaşi, Şcoala 
Doctorală.pp. $112-125$.

Kilinç Y. et al., 2018, Evaluation of technical performance of pipes in water distribution systems by analytic hierarchy process. Sustainable Cities and Society 42 (2018), pp. 1321.

Lambert, A. O., Hirner, W., 2000, Losses from Water Supply Systems: Standard Terminology and Recommended Performance Measures. IWA Blue Pages. pp. 1-13.

Luca, M., Bălan, Anca, Toma, D., Apetroi, I. V., Avram, Mihaela, 2015, The adduction pipes management on limiting water loss. Proceedings IWA Regional Conference: "Water Loss Management 2015", ARA Publishing, Bucureşti, Romania, pp. 348 356, ISBN 978-606-93752-6-6.

Majetich, S., Zaibert, A., 2016, Advanced Leak Detection Technology Utilizing Satellite Imagery. AWWA Webinar Program: ACE16 Preview: Water Loss.

Postăvaru, A., GRP - STREAM EM, 2016, Workshop "Detectivii apei pierdute", Bucureşti.

Racovițeanu, G., Dinet, E., Boer, A., 2015, Assessment of the current level of the nonrevenue water in Romania. Proceedings IWA Regional Conference: "Water Loss Management 2015”, ARA Publishing, Bucureşti, Romania, pp. 14 - 24, ISBN 978606-93752-6-6.

Schumi, P., 2017, Advanced leak detection technology utilizing satellite imagery. Water Asset Management Conference, Boston U.S.A., October 11, 2017.

Shakmak, B., Al-Habaibeh, A., 2015, Detection of water leakage in buried pipes using infrared technology; A comparative study of using high and low resolution infrared cameras for evaluating distant remote detection. 2015 IEEE Jordan Conference on Applied Electrical Engineering and Computing Technologies (AEECT), pp. 1-7.

Sturm, R., Gasner, K., Andrews, L., 2015, Water Audits in the United States: A Review of Water Losses and Data Validity. Water Research Foundation, U.S.A., ISBN 978-160573-224-4.

Tischler, M. A., 2003, Integrating ground-penetrating radar, geographic information systems and global positioning systems for 3-dimensional soil modeling. Master Degree Thesis. University of Florida. pp. $33-41$. 